\title{
Advantages and limitations of using national survey datasets in child and adolescent research
}

Yoon Lee, MD

Department of Pediatrics, Korea University College of Medicine, Seoul, Korea

\section{Key message}

The Korean National Health and Nutrition Examination Survey and the Korea Youth Risk Behavior Web-based Survey are major nationwide health and nutrition surveys in Korea. Although these surveys have some limitations of cross-sectional sample surveys, the accumulated data are valuable and provide new prospects for understanding public health depending on the interpretation method.

The Korean National Health and Nutrition Examination Survey (KNHANES) and Korea Youth Risk Behavior Web-based Survey (KYRBS) are major nationwide health and nutrition surveys in Korea.

The review article entitled "Dietary intake and nutritional status of Korean children and adolescents: a review of national survey data" summarizes the findings of KNHANES and KYRBS data-based papers that focus on infant feeding practices, and the dietary intake and nutritional status of Korean infants, children, and adolescents within the last 5 years.

The author organized the study findings well with the major issues of interest: dietary behavior, nutritional status, and nutrition-related chronic diseases. This study greatly aids our understanding of the results of previous studies.

By following the study results presented by the author, readers might outline the nutritional status of the Korean population as follows:

(1) Mixed feeding of formula and breast milk is the most common feeding practice in Korea for children aged 1-3 years, and the exclusive breastfeeding rate decreased over time. ${ }^{1,2)}$

350

300

250

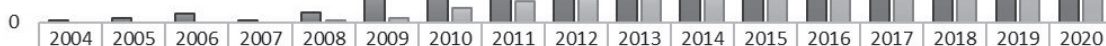

\begin{tabular}{|c|c|c|c|c|c|c|c|c|c|c|c|c|c|c|c|c|c|}
\hline $\begin{array}{c}\text { Search query: "Korea National Health and Nutrition } \\
\text { Examination Survey" }\end{array}$ & 1 & 2 & 4 & 1 & 5 & 13 & 19 & 35 & 61 & 112 & 176 & 232 & 227 & 224 & 254 & 251 & 293 \\
\hline $\begin{array}{c}\text { Search query: The Korea Youth Risk Behavior Web-based } \\
\text { Survey }\end{array}$ & 0 & 0 & 0 & 0 & 1 & 2 & 7 & 10 & 12 & 17 & 15 & 26 & 31 & 27 & 32 & 35 & 57 \\
\hline
\end{tabular}

口Search query: "Korea National Health and Nutrition Examination Survey"

घSearch query: The Korea Youth Risk Behavior Web-based Survey

Fig. 1. PubMed timeline results for queries related with Korean National Surveys: the number of papers based on KNHANES and KYRBS data has sharply increased yearly and is several times higher than that of the studies referred to in the review. ${ }^{3)}$ KNHANES, Korean National Health and Nutrition Examination Survey; KYRBS, Korea Youth Risk Behavior Web-based Survey. 
(2) One quarter of Koreans introduce complementary foods to their infants at 4-5 months of age, while $64.3 \%$ do so at 6-7 months of age.

(3) Unhealthy eating habits, such as skipping breakfast, eating fast/processed foods, and ingesting sugar-sweetened beverages, have increased continuously.

(4) Although sodium intake has decreased, it remains higher than the World Health Organization recommendation.
(5) A considerable prevalence of vitamin D insufficiency was identified. Some studies suggest associations between vitamin D deficiency and some chronic diseases.

(6) An increase in obesity and allergic diseases was observed.

Most of the studies referred in current review focused on changes in the prevalence or tendencies toward certain nutritional behaviors, conditions, and nutrition-related chronic diseases.

However, several studies focused on the association or risk of

Table 1. National Surveys Embedded in Broader Health Surveys

\begin{tabular}{|c|c|c|c|c|}
\hline Country & $\begin{array}{l}\text { Survey (designation of the } \\
\text { general health survey) }\end{array}$ & $\begin{array}{l}\text { Organism/coordinating } \\
\text { institution }\end{array}$ & Health and lifestyle measurements & Additional comments \\
\hline $\begin{array}{l}\text { South } \\
\text { Africa }\end{array}$ & $\begin{array}{l}\text { South African National Health } \\
\text { and Nutrition Examination } \\
\text { Survey (SANHANES-1) }\end{array}$ & $\begin{array}{l}\text { Human Sciences Research } \\
\text { Council and the Medical } \\
\text { Research Council }\end{array}$ & $\begin{array}{l}\text { Blood lipids, physical examination, pulse } \\
\text { rate, cardiovascular fitness }\end{array}$ & $\begin{array}{l}\text { This is the first survey (2013). Only a } \\
\text { food frequency questionnaire is used } \\
\text { as dietary intake assessment method }\end{array}$ \\
\hline Australia & $\begin{array}{l}\text { National Nutrition and Physi- } \\
\text { cal Activity Survey (NNPAS) } \\
\text { Australian Health Survey } \\
\text { (AHS) }\end{array}$ & $\begin{array}{l}\text { Australian Bureau of Sta- } \\
\text { tistics }\end{array}$ & $\begin{array}{l}\text { Physical examination (blood pressure } \\
\text { [BP], self-assessed health, conditions) } \\
\text { Lifestyle survey (alcohol consumption, } \\
\text { medication, smoking, physical activity) }\end{array}$ & $\begin{array}{l}\text { AHS started in 1977-1978; NNPAS } \\
\text { started in 1995; both surveys were } \\
\text { combined since } 2011-2013\end{array}$ \\
\hline China & $\begin{array}{l}\text { China Health and Nutrition } \\
\text { Survey (CHNS) }\end{array}$ & $\begin{array}{l}\text { National Institute of Nutri- } \\
\text { tion and Food Safety } \\
\text { from the China Center } \\
\text { for Disease Control and } \\
\text { Prevention }\end{array}$ & $\begin{array}{l}\text { Physical examination: BP, skinfold thick- } \\
\text { ness, conditions (goiter, eye diseases, } \\
\text { handicap, reproductive health for } \\
\text { women), ever-married survey, com- } \\
\text { munity survey, energy expenditure }\end{array}$ & $\begin{array}{l}\text { Both surveys were initiated together } \\
\text { since } 1991\end{array}$ \\
\hline Japan & $\begin{array}{l}\text { National Health and Nutrition } \\
\text { Survey (J-NNS) }\end{array}$ & $\begin{array}{l}\text { National Institute of Health } \\
\text { and Nutrition }\end{array}$ & $\begin{array}{l}\text { Physical examination (BP, number of } \\
\text { steps per day, use of medication, phy- } \\
\text { sical activity); Lifestyle survey (smoking, } \\
\text { alcohol, dental health, resting, physical } \\
\text { activity) }\end{array}$ & $\begin{array}{l}\text { J-NNS started since } 1946 \text { and both } \\
\text { health and nutrition components } \\
\text { were initially integrated }\end{array}$ \\
\hline $\begin{array}{l}\text { South } \\
\text { Korea }\end{array}$ & $\begin{array}{l}\text { Korean National Health and } \\
\text { Nutrition Examination Sur- } \\
\text { vey (KNHANES) }\end{array}$ & $\begin{array}{l}\text { Ministry of Food and Drug } \\
\text { Safety }\end{array}$ & $\begin{array}{l}\text { Health examination (hypertension, diabe- } \\
\text { tes, dyslipidemia, hepatitis, liver func- } \\
\text { tion, chronic kidney disease, anemia, } \\
\text { heavy metal, chronic obstructive pul- } \\
\text { monary disease, dental caries, perio- } \\
\text { dontal disease, visual acuity, eye dis- } \\
\text { ease, hearing, ear, nose and throat } \\
\text { disease, tuberculosis, osteoarthritis, } \\
\text { osteoporosis, muscular strength, } \\
\text { thyroid disease), lifestyle survey (smok- } \\
\text { ing, alcohol, weight control, vaccination, } \\
\text { mental health, oral health, healthcare } \\
\text { utilization, medical conditions) }\end{array}$ & $\begin{array}{l}\text { The National Health and Health Be- } \\
\text { havior Survey started in } 1971 . \\
\text { The National Nutrition Survey stared } \\
\text { since } 1969 \text {. } \\
\text { Both surveys were combined since } \\
1998 \text {. } \\
\text { The sample represents the total non- } \\
\text { institutionalized civilian population of } \\
\text { Korea. }\end{array}$ \\
\hline Malaysia & $\begin{array}{l}\text { Malaysian Adult Nutrition } \\
\text { Survey (MANS) } \\
\text { National Health and Morbi- } \\
\text { dity; Survey (NHMS) }\end{array}$ & Ministry of Health & $\begin{array}{l}\text { Medical examination (diabetes, hyper- } \\
\text { tension, dyslipidemia, mental health, } \\
\text { home injury, healthcare demand), } \\
\text { lifestyle (smoking, physical activity, } \\
\text { alcohol consumption) }\end{array}$ & $\begin{array}{l}\text { The NHMS was conducted since } 1986 . \\
\text { The MANS was established since } 2004 \\
\text { and integrated to NHMS. } \\
\text { The South East Asian Nutrition Survey } \\
\text { (SEANUTS) is a four-country multi- } \\
\text { stage cluster design study and also } \\
\text { delivers important nutrition and } \\
\text { health information for Malaysia }\end{array}$ \\
\hline Canada & $\begin{array}{l}\text { Canadian Community Health } \\
\text { Survey Nutrition (CCHS) }\end{array}$ & Statistics Canada & $\begin{array}{l}\text { Medical examination (general health, } \\
\text { chronic conditions, handicap), lifestyle } \\
\text { (smoking, physical activity, alcohol } \\
\text { consumption) }\end{array}$ & $\begin{array}{l}\text { The Canadian Nutrition Survey started } \\
\text { since 1970-1972 prior to the Cana- } \\
\text { dian Health Survey started in 1978- } \\
\text { 1979, and both have been combined. } \\
\text { Includes indigenous people's health } \\
\text { and women's health are included }\end{array}$ \\
\hline Mexico & $\begin{array}{l}\text { Mexican Health and Nutrition } \\
\text { Survey (ENSANUT) }\end{array}$ & $\begin{array}{l}\text { National Institute of Public } \\
\text { Heath }\end{array}$ & $\begin{array}{l}\text { Physical examination (anemia, diabetes, } \\
\text { hypertension, reproductive health, } \\
\text { mental health, vaccination), lifestyle } \\
\text { (smoking, alcohol) }\end{array}$ & $\begin{array}{l}\text { National health surveys have been } \\
\text { conducted since 1986, but the dietary } \\
\text { component was integrated since } 2006\end{array}$ \\
\hline The USA & $\begin{array}{l}\text { National Health and Nutrition } \\
\text { Examination Survey (conti- } \\
\text { nuous NHANES) }\end{array}$ & $\begin{array}{l}\text { National Center for Health } \\
\text { Statistics from the Cen- } \\
\text { ters for Disease Control } \\
\text { and Prevention }\end{array}$ & $\begin{array}{l}\text { Physical examination (audiometry, human } \\
\text { papillomavirus, oral health, hyperten- } \\
\text { sion, heart, sexually transmitted dis } \\
\text { eases). Lifestyle (e.g., smoking, alcohol) }\end{array}$ & $\begin{array}{l}\text { National health surveys were collected } \\
\text { since 1950s. } \\
\text { The first NHANES started in } 1971 \text { as a } \\
\text { combination both health and nutri } \\
\text { tion components }\end{array}$ \\
\hline
\end{tabular}

Adapted from Huybrechts et al. Proc Nutr Soc 2017;76:549-67, with permission of Cambridge University Press. ${ }^{8)}$ 
chronic diseases that could be caused by or related to nutritional issues, and the authors summarized them well in Tables 3-7.

In the current review, the authors focused only on nutrition studies, while a far greater number of studies based on KNHANES and KYRBS data were conducted, which can be checked easily in an online database (Fig. 1).3)

As mentioned in the review, the KNHANES has been conducting 3-year surveys since 1998 with reference to National Health and Nutrition Examination Survey (NHANES) in the United States, and it has been implemented annually since the fourth phase in 2007.

The survey collects information on socioeconomic status, health-related behaviors, quality of life, healthcare utilization, anthropometric measures, biochemical and clinical profiles for noncommunicable diseases, and dietary intakes using a health interview, health examination, and nutrition survey. ${ }^{4)}$

The latest updated available data are of 2018, corresponding to the 3 rd year of the 7 th phase, and the first year of the 8 th phase is scheduled to be opened soon. ${ }^{5)}$

Conversely, the KYRBS is an annual school-based national cross-sectional survey that monitors health risk behaviors associated with noncommunicable diseases and unintentional injuries among Korean adolescents conducted by the Korean Ministry of Education, Ministry of Health and Welfare, and the Korea Centers for Disease Control and Prevention since 2005, and latest available data are of 2019.6,7)

In fact, the beautiful part of KNHANES-based research is that the KNHANES is a longitudinal national representative dataset that provides general (but detailed) health-related information and biochemical and clinical profiles simultaneously.

There are few nationwide surveys worldwide that provide biochemical and clinical/nutritional profiles simultaneously like the KNHANES, and considering the breadth and depth of the collected data and its accumulation over the period, the KNHANES is almost unique globally (Table 1). ${ }^{8)}$

Although longitudinal data are available, it is necessary to consider that the KNHANES itself is a cross-sectional sample survey; hence, a temporal comparison must be performed cautiously. Furthermore, not all subjects of the KNHANES completed the biochemical studies, the enrollment criteria of which changed over time.

For a pediatrician, KNHANES has some disappointing aspects; detailed food frequency, food, and dietary intake surveys were obtained only in subjects aged $>19$ years, while the biochemical screenings were performed only in patients aged $\geq 10$ years. ${ }^{5)}$

Thus, KYRBS may be a more attractive alternative to pediatricians since it focused on adolescents. In fact, KYRBS is a quite useful questionnaire survey, and it would be difficult to improve upon it to evaluate adolescent health, diet, and risk behavior.

However, it still has the limitations of a cross-sectional sample survey. Because KYRBS is an anonymous self-reported survey, it is also necessary to consider the sincerity of the subjects' responses.

The KNHANES has been accumulating data for more than
20 years versus 15 years for the KYRBS. Thus, the accumulated data are valuable. However, once these data are combined with other social/demographic/public health data (e.g., national consumption of dairy food, national health insurance claim data of specific diseases), new prospects for understanding public health can be provided. Furthermore, the current coronavirus disease 2019 pandemic has dramatically changed people's health and dietary behaviors, and upcoming survey results would obviously reflect them. I believe that these research issues quite interesting and promising.

\section{Footnotes}

Conflicts of interest: No potential conflict of interest relevant to this article was reported.

See the article "Dietary intake and nutritional status of Korean children and adolescents: a review of national survey data" via https://doi.org/10.3345/cep.2020.01655.

\section{References}

1. Baek Y, Shim JE, Song S. Dietary intake of fat and fatty acids by 1-5-yearold children in Korea: a cross-sectional study based on data from the sixth Korea National Health and Nutrition Examination Survey. Nutr Res Pract 2018;12:324-35.

2. Kim Y, Lee SG, Kim SA, Song Y, Chung J, Park M. Nutritional status of Korean toddlers: from the Korean National Health and Nutrition Examination Survey 2007-2009. Korean J Pediatr Gastroenterol Nutr 2011;14:161-70.

3. National Center for Biotechnology Information (NCBI) [Internet]. Bethesda (MD): National Library of Medicine (US), National Center for Biotechnology Information; [1988]- [cited 2020 Dec 24]. Available from: https://pubmed.ncbi.nlm.nih.gov.

4. Kweon S, Kim Y, Jang MJ, Kim Y, Kim K, Choi S, et al. Data resource profile: the Korea National Health and Nutrition Examination Survey (KNHANES). Int J Epidemiol 2014;43:69-77.

5. The Korea National Health and Nutrition Examination Survey [Internet]. Sejong (Korea): Ministry of Health and Welfare of Korea; 2020 [cited 2020 Dec 23]. Available from: http://knhanes.cdc.go.kr.

6. Kim Y, Choi S, Chun C, Park S, Khang YH, Oh K. Data resource profile: the Korea Youth Risk Behavior Web-based Survey (KYRBS). Int J Epidemiol 2016;45:1076-1076e.

7. The Korea youth risk behavior web-based survey [Internet]. Cheongju (Korea): Korea Centers for Disease Control and Prevention; 2020 [cited 2020 Dec 21]. Available from: https://www.cdc.go.kr/yhs/home.jsp.

8. Huybrechts I, Aglago EK, Mullee A, De Keyzer W, Leclercq C, Allemand P, et al. Global comparison of national individual food consumption surveys as a basis for health research and integration in national health surveillance programmes. Proc Nutr Soc 2017;76:549-67.

How to cite this article: Lee Y. Advantages and limitations of using national survey datasets in child and adolescent research. Clin Exp Pediatr 2021;64:648-70. https://doi.org/10.3345/ cep. 2020.02110 